\title{
The Role of Entrepreneurial Personality on Competitive Advantages and Corporate Image based on digital
}

\author{
Hari Muharam, Harmon Chaniago
}

\begin{abstract}
The purpose of this study is to investigate the impact of store image on purchase intention and buying decision based on the perceptions and thoughts of Muslim consumers. To be the sample, 100 consumers who are used to shopping at modern minimarkets were involved. To get a fit model, data used were in 1000 bootstrapping data. The store image research results consist of retail facility dimensions (physical completeness, display), store service dimensions (empathy, professional sellers) and store environment dimensions (comfortable environment, lighting). Store services and store environments are proven to be influential in purchase intention. Whereas, store facility was only correlates with store service and store environment and was not proven to affect purchase intention and buying decisions. The purchase intention has proven to influence purchasing decisions. This study found that factors like empathy, professional sellers, pleasant environment, lighting, physical equipment and displays, influence Muslim customers' interest on purchasing things.
\end{abstract}

Index Terms: Store Image, Store Services, Store Environment, Store Facility, Purchase Intention, Buying Decision

\section{INTRODUCTION}

Since 1990 various types of modern retailers have emerged in Indonesia ranging from supermall, malls, supermarkets, minimarkets and stalls. Retail is a marketing activity of the company by selling various kinds of community needs. It is the link between the distributor and the final customer. Stanton (1994) stated that retail sells goods to consumers. One of retailer types that available in Indonesia is modern minimarkets. This modern minimarkets have developed to the countryside. As a result, the traditional retail market took over minimarkets. There is not infrequent friction between traditional retailers and modern retail types of minimarkets. Increasingly, Indonesians prefer to shop in modern retailers. There are several famous modern minimarket brands that operate in Indonesia; Indomart, Alfamart, Yomart, Borma, 7eleven, Yogya.

The development of retail is caused by changes in people's lifestyles. Retail entrepreneurs spoil consumers by providing a comfortable place, strategic location, fixed prices and ease of finding the desired product. Data on the development of modern retail in Indonesia from 2013 - 2015, it shows a growth of $2.3 \%$ each year (1) When this research was conducted, most retailers were owned or affiliated with a large group of companies. Yet, what makes it similar that their

Revised Manuscript Received on September 22, 2019.

Hari Muharam, Faculty of Management, Universitas Pakuan, Bogor Jawa Barat, Indonesia, abcd@gmail.com

Harmon Chaniago, Politeknik Negeri Bandung, Jawa Barat, Indonesia consumers are mostly Muslim, because $80 \%$ of the 256 million people in Indonesia are Muslim.

Such large potential consumers become opportunities and need to be managed by retail entrepreneurs. Thus, each retailer seeks to attract prospective customers by presenting excellence such as a safe and comfortable place, the price of competitive goods and complete shop facilities. The results of research conducted by (2) shows that a positive store image becomes a separate magnet for consumers to buy goods at minimarkets known as store image. But the store image criterion has not been agreed by experts.

Some studies have been conducted on the role of store image to increase purchase intention and buying decisions. (3) stated that the intention to buy for clothing retailing has become a concern of today's researchers. Likewise, the role of store image in retailers is selling people's needs. There is a suspicion that store image not only increases purchasing decisions but also encourages consumers to be loyal. This research tries to prove it empirically.

But there is still little research on store image that is seen from the perspective of Muslim consumers. Most studies are conducted from consumer perspectives in general, such as the study of (2) (4) who also conduct research from the point of view of consumer fields in general. (5) has conducted store image research on small retailers from the perspective of Indian consumers. This means that store image can be seen from the point of view of consumers and there is no standard agreement in measuring store image (2) $(6,7)$ Based on this, the study empirically investigates store image and personal purchasing decisions from the perspective of Muslim consumers. The findings of the study also are beneficial for retail store managers in increasing store image for consumers who mostly are Muslims.

Buying interest is defined as the effort of consumers to buy products or services from producers. Buying interest is a positive response from the feelings of consumers on a stored item which is presented in one particular place or area or the emergence of consumer desires and attention to goods or services. At the stage of buying interest, consumers have not made a purchase, he or she just comes to see, pay attention and look for information about the product. The emergence of consumer interest in an item in a retail store can be used as evidence of the emergence of a desire of the consumer to fulfill their needs with the goods. The buyer's interest has already shown. 


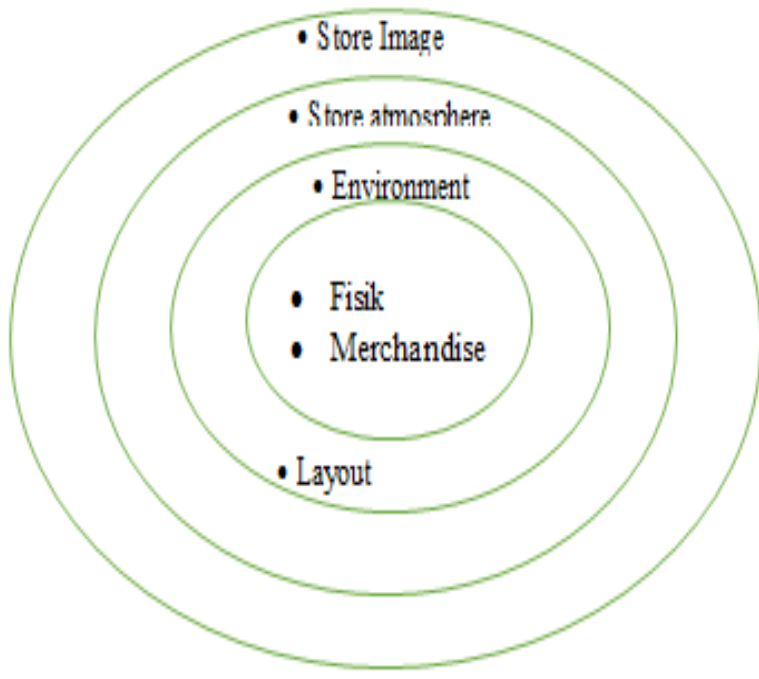

Fig 1.The Concept of Store Image

\section{LITERATURE REVIEW}

The explanation above explains that store image involves a description of what is seen, perceived, thought and belief in consumer memory about various attributes of a store. It is also concluded that store image is functional between physical and non-physical factors such as the layout of goods, cleanliness of rooms, merchandise, etc with non-physical factors such as store atmospheres, speed of service to complaints, friendliness of employees, accuracy of the cashier, all of which can be accepted and felt by the consumers of the store.

Retailers need to know what is needed to build an image to consumers. This image can be felt by the five human senses. The components that can be used as a basis for motivating consumers to shop at retail stores are: physical facilities, merchandise, comfort and service / personnel. Konuk's research on food retailers proves that building a positive store image will increase purchase quality and perceived value, this will ultimately increase purchase intention. He suggested that investment retailer increase store positive image.

Retailers have a good idea of determining the determinants of a consumer's choice in shopping. Retailers and managers are required to be careful in: studying purchasing decisions, understanding information received by consumers, the process of interest and criteria for consumers choosing products. There have been many studies conducted on purchasing decisions. Organizational purchasing decisions (manufacturing and company) are different from consumer purchasing decisions personally. This research investigates the prospects of purchasing decisions from the personal side of Muslims. Some academic witing explain that personnel purchasing decisions includes purchase intention. Payment methods are used, attention to products, promotions, places, prices for shopping. In retail actions, to visit the store, consumer attention to goods is also part of personal purchasing decisions. The point is that purchasing decisions also have multi variants. Purchasing decisions for the needs of daily necessities can be different. This is due to the function of goods, products, prices, time needs and accessories offered by the seller. This research attempts to look at and analyze specifically the decisions of Muslim retail consumer buyers from the dimensions of purchase intention and purchasing decisions.

\section{METHODOLOGY/MATERIALS}

The research method used is the confirmatory survey. Data analysis using SEM (Structural Equation Modeling) supported by AMOS Software version 23.

Data is processed in two stages, step 1 processes all samples. The result is abnormal data. The second stage of the modification model was carried out by booting 1000 data to obtain a fit model. From the models that have been fit the analysis continues.

The object of research is store image and purchasing decision (buying decision) from Muslim consumers who shop at minimarkets. Store image consists of 4 dimensions, while the purchase decision consists of 2 dimensions. Store image is measured from 10 indicators and measured purchasing decisions from 4 indicators as shown in table 1.

Table 1

\begin{tabular}{|c|c|c|}
\hline Variable & Dimension & Indicator $\mathrm{n}$ symbol \\
\hline \multirow[t]{10}{*}{ Store Image } & Store Facility & Display (x1) \\
\hline & & $\begin{array}{l}\text { Physical completeness } \\
\qquad(\mathrm{x} 2)\end{array}$ \\
\hline & & Layout (x3) \\
\hline & Merchandise & Quality of the product $(\mathrm{x} 4)$ \\
\hline & & Price (x5) \\
\hline & Store & Environment (x6) \\
\hline & Environment & Lighting (x7) \\
\hline & Store Services & Emphaty (x8) \\
\hline & & Operational Hours (x9) \\
\hline & & $\begin{array}{l}\text { Profesional/Human } \\
\text { resource }(\mathrm{x} 10)\end{array}$ \\
\hline Buying & Purchase & Attention on goods (y1) \\
\hline \multirow[t]{3}{*}{ Decision } & Intention & $\begin{array}{l}\text { The desire to buy things } \\
\text { (y2) }\end{array}$ \\
\hline & Payment Decision & Payment method (y3) \\
\hline & & Payment time (y4) \\
\hline
\end{tabular}

The design of the research model and the inter-dimensional linkages are as follows: 


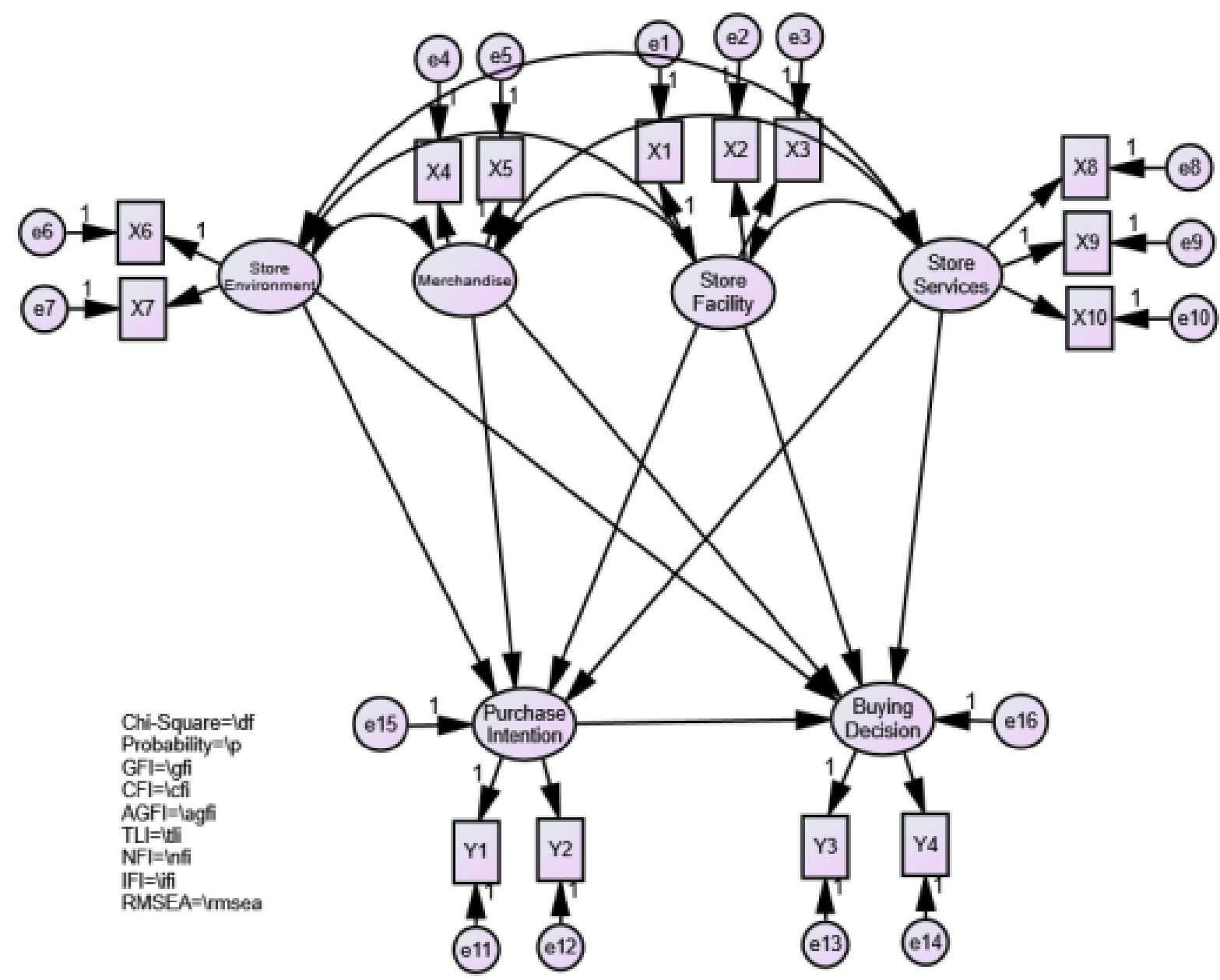

Fig 2. Effect design store image on Muslim consumer purchasing decisions.

\section{RESULTS AND FINDINGS}

Store image is the overall impression and value that consumers have in mind about a store such as a shop that consumers feel the price of goods which is expensive or vice versa. A shop that sells quality goods, a convenient store, a shop with professional services prove that the price image affects store image. Researchers have studied and discussed the differences in retail attributes that affect store image. Overall, it was found in the form of: merchandise, product prices, physical quality of the store, store atmosphere, layout, service, comfort, price level and various others. Each researcher can formulate store image attributes differently. Therefore, Store image can be defined from various variants. There is no standard agreement on the store image criteria Store image can be seen from the psychological dimension / what is felt by consumers and can be seen from the dimensions of function / congress such as: physical retail, functional, real) or seen a combination of consumers' thoughts and feelings about a store. They call store image as the totality of what is seen, thought and felt by consumers about the characteristics of a retail store Store image affects the perceived quality and encourages consumers to make purchases Store image is an asset of a store, store image as a personality owned by a store. It is formed from several combinations of variants such as: merchandise, services, customers, physical facilities, comfort, promotion / advertising, layout, employees, Variant transaction methods can develop according to the location, culture and needs of

each retailer. Another opinion reminded of the importance of understanding different local needs in providing retail facilities and infrastructure.

The results of processing data with factor analysis obtained information that some loading factors are not significant as in table 2 below:

Table 2 Level of Significance of each measurement factor

\begin{tabular}{|c|c|c|c|}
\hline$\frac{\frac{\text { Indicator }}{\text { (Measurenmen }}}{\underline{\mathrm{t}} \text { ) }}$ & $\begin{array}{c}\text { Squared } \\
\text { Multiple } \\
\text { Correlations/ } \\
\mathrm{R}^{2} \\
(\text { Standar } \\
>50 \%) \\
\end{array}$ & $\begin{array}{l}\text { Probability/ } \\
\text { Significant }\end{array}$ & $\begin{array}{l}\text { Calculat } \\
\text { ion } \\
\text { result of } \\
\text { Goodne } \\
\text { ss of fit }\end{array}$ \\
\hline 1 & 2 & 3 & 4 \\
\hline $\begin{array}{l}\text { Purchasing } \\
\text { Intention }\end{array}$ &,- 492 & $\begin{array}{l}\text { Nonsignifica } \\
\mathrm{nt}\end{array}$ & \multirow{8}{*}{$\begin{array}{l}\text { Chi-sq } \\
\text { uare: } \\
120.70 \\
5 ; \\
\mathrm{P}=0 ; \\
\mathrm{Cr}=18 \\
068 ; \\
\mathrm{Cmin} / \\
\mathrm{df}= \\
1,947 ; \\
\mathrm{GFI}= \\
0,868 ; \\
\text { AGFI= } \\
0,777 ;\end{array}$} \\
\hline Buying Decision &, 873 & $\begin{array}{l}\text { Nonsignifica } \\
\mathrm{nt}\end{array}$ & \\
\hline X8 (Emphaty) & ,541 & Significant & \\
\hline X3 (Layout) & ,631 & Significant & \\
\hline X5 (price) & ,624 & Significant & \\
\hline $\begin{array}{l}\text { X4(quality of } \\
\text { products) }\end{array}$ & ,734 & Significant & \\
\hline $\begin{array}{l}\text { X2(Physical } \\
\text { completeness) }\end{array}$ & ,580 & Significant & \\
\hline $\begin{array}{l}\text { Y3 (payment } \\
\text { media) }\end{array}$ & ,672 & Significant & \\
\hline
\end{tabular}




\begin{tabular}{|c|c|c|c|}
\hline$\frac{\begin{array}{c}\text { Indicator } \\
\text { (Measurenmen }\end{array}}{\underline{\mathrm{t}} \text { ) }}$ & $\begin{array}{c}\text { Squared } \\
\text { Multiple } \\
\text { Correlations/ } \\
\mathrm{R}^{2} \\
\text { (Standar } \\
>50 \%)\end{array}$ & $\begin{array}{c}\text { Probability/ } \\
\text { Significant }\end{array}$ & $\begin{array}{l}\text { Calculat } \\
\text { ion } \\
\text { result of } \\
\text { Goodne } \\
\text { ss of fit }\end{array}$ \\
\hline $\begin{array}{l}\text { Y4 (payment } \\
\text { time) }\end{array}$ &, 595 & Significant & \multirow{8}{*}{$\begin{array}{l}\text { TLI=0, } \\
879 ; \\
\text { CFI=0, } \\
917 ; \\
\text { IFI=0, } \\
921 ; \\
\text { NFI=0 } \\
\text {,850 } \\
\text { RMSEA= } \\
0,098\end{array}$} \\
\hline $\begin{array}{l}\text { Y1(Attentiion to } \\
\text { goods) }\end{array}$ & ,654 & Significant & \\
\hline $\begin{array}{l}\text { Y2 (desire to } \\
\text { shop) }\end{array}$ &, 574 & Significant & \\
\hline $\begin{array}{l}\text { X10 } \\
\text { (Professional } \\
\text { seller) }\end{array}$ & ,309 & Significant & \\
\hline X9 (Jam operasi) & ,397 & Significant & \\
\hline $\begin{array}{l}\text { X6 } \\
\text { (Environment) }\end{array}$ & ,271 & Significant & \\
\hline X7 (Lighting) & ,552 & Significant & \\
\hline X1 (Displaying) &, 519 & Significant & \\
\hline
\end{tabular}

From table 2, it shows that data is not normally distributed $(\mathrm{Cr}=18,068)$ and there are still many loading factor $<0.05$ or not significant such as: purchase intention and buying decision. Factors with no significant correlation coefficient and a multiple square value of $<0.5$ were dropped or excluded from the research model (8) unless theoretically it is needed. Some indicators are not fit, therefore modification of the model is done. The results of the second processing and modification of the model obtained information such as table 3 below:

Table 3. Level of Significance of each measurement factor after the model in Revision

\begin{tabular}{|c|c|c|c|}
\hline$\frac{\underline{\text { Indicators }}}{\text { (Measurenment }}$ & $\begin{array}{c}\text { Squared } \\
\text { Multiple } \\
\text { Correlations/ } \\
\mathrm{R}^{2} \\
\text { (Standard } \\
>50 \% \text { ) }\end{array}$ & $\begin{array}{c}\text { P/ Significant } \\
\text { Level }\end{array}$ & $\begin{array}{l}\text { The } \\
\text { second } \\
\text { calculation } \\
\text { result to } \\
\text { Goodness } \\
\text { of fit }\end{array}$ \\
\hline 1 & 2 & 3 & 4 \\
\hline $\begin{array}{l}\text { Purchase } \\
\text { Intention }\end{array}$ & ,887 & 0,001 & \multirow{13}{*}{ 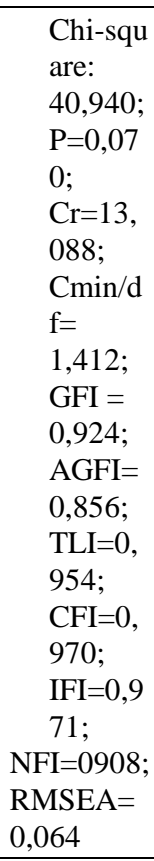 } \\
\hline Buying Decision & ,898 & 0 & \\
\hline $\begin{array}{l}\mathrm{X} 2 \text { (physical } \\
\text { completeness) }\end{array}$ & ,429 & 0 & \\
\hline $\begin{array}{l}\text { Y3 (Payment } \\
\text { method/ media) }\end{array}$ & ,710 & 0 & \\
\hline $\begin{array}{l}\text { Y4 (payment } \\
\text { time) }\end{array}$ & ,563 & 0 & \\
\hline $\begin{array}{l}\text { Y1(attention to } \\
\text { products/goods) }\end{array}$ & ,576 & 0 & \\
\hline $\begin{array}{l}\text { Y2 (desire to } \\
\text { shop) }\end{array}$ & ,506 & 0 & \\
\hline $\begin{array}{l}\text { X10(Professional } \\
\text { seller) }\end{array}$ & ,366 & 0 & \\
\hline X8 (emphaty) & ,669 & 0 & \\
\hline X6 (environment) &, 263 & 0 & \\
\hline X7 (lighting) & ,709 & 0 & \\
\hline $\mathrm{X} 1$ (display) & ,635 & 0 & \\
\hline & & & \\
\hline
\end{tabular}

$* * *=$ significant to 0

The results of the second processing are model indicators such as Table 3 with Chi-square 40,940; Probability or significant count $0.070, \mathrm{Cmin} / \mathrm{df}=1.412 ; \mathrm{GFI}=0924$; AGFI $=0.856 ; \mathrm{TLI}=0.954, \mathrm{CFI}=0.970 ; \mathrm{IFI}=0.971, \mathrm{NFI}=908$ and RMSEA $=0.064$. The results of the calculation of the data show that the model obtained is fit and reliable (8) (9). All coefficient of purchase intention path are significant buying decision. Even though the model obtained is fit, the data is not normally distributed ( $\mathrm{Cr} 13,088)$, therefore bootstrapping is needed on 1000 data. The results after bootstrapping are as follows:

ML discrepancy (implied vs sample) (Default model)

$\mathrm{N}=1000$

Mean $=41,129$

S. e. $=, 446$

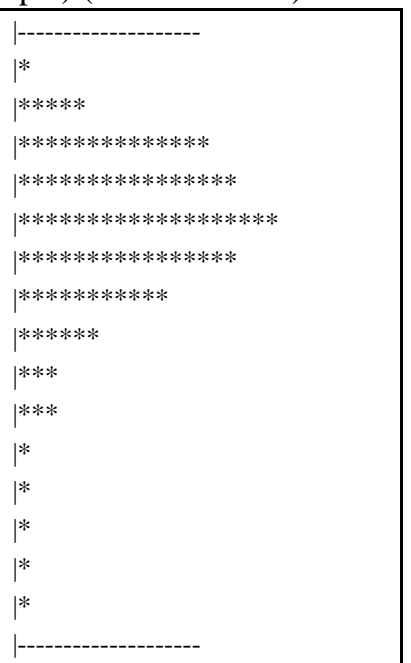

Figure 3 Results of bootstrapping

Processing data using bootstrapping in this study causes the data to meet the requirements for use and the processing process continues. The following table informs data before and after bootstrapping of 1000 data.

Table 4. Comparison of Results Before and After Bootstrapping

\begin{tabular}{|l|l|l|c|c|}
\hline & Original & Bootstrapping & $\begin{array}{c}\text { Critical } \\
\text { Value } \\
\text { on P= } \\
5 \%\end{array}$ & Description \\
\hline DF & 29 & - & 0,070 & - \\
\hline Chi-Square & 40,940 & 41,129 & 0,457 & $\begin{array}{c}\text { The original } \\
\text { critical value is } \\
\text { smaller than } \\
\text { bootstrapping } \\
\text { or there is no } \\
\text { difference } \\
\text { between the } \\
\text { model and the } \\
\text { data (model } \\
\text { fit) }\end{array}$ \\
\hline
\end{tabular}

Data on table 4 provides an illustration that with indigo DF 29 (before bootstrapping) the critical value is $0.070<0.457$ (after bootstrapping). This means there is no difference in model with data (model fit on 1000 bootstrapping). Processing data with bootstrapping obtained a fit model as shown in the following picture: 


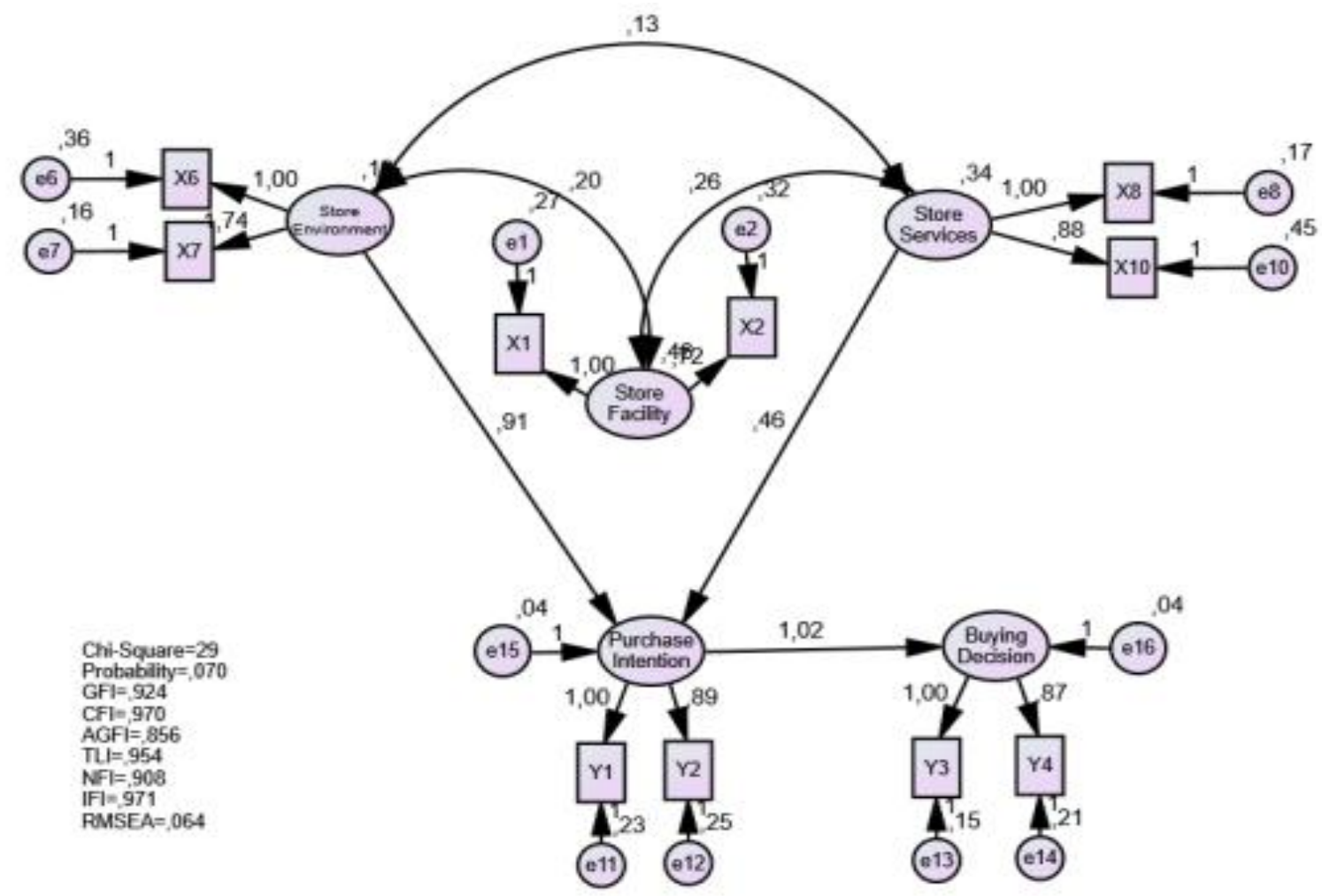

Figure 4 Effect of Store Environment, Store Services on Purchase intention and Buying Decision (Revision model)

From the results of data processing found (see Figure 4), it is found that store image of a retail store in the view of Muslim consumers only consists of store environment dimensions (environment or lighting), store services dimensions (empathy and professional sellers) and store facility dimensions (display and physical completeness). Store facility only has a correlation with store environment and store services. It does not directly affect the purchase intention and buying decision. The data also shows only the dimensions of the store environment and dimensions of store services that directly affect purchase intention. This means that only empathy factors, skilled or professional sellers, environment and comfortable lighting will be able to increase the buying interest of Muslim consumers. The test results also prove that purchase intention has an effect of $94.8 \%$ on Muslim consumer purchasing decisions, as presented in table 5 .

Table 5. Direct and indirect influence of Store Image on Purchase Intention and Buying Decision

\begin{tabular}{|c|c|c|c|}
\hline \multirow{2}{*}{ Predictor } & \multicolumn{2}{|c|}{ Total Effect } & \multirow{2}{*}{$\begin{array}{c}\text { Significant } \\
\text { Level }\end{array}$} \\
\cline { 2 - 3 } & $\begin{array}{c}\text { Purchase } \\
\text { Intention }\end{array}$ & $\begin{array}{c}\text { Buying } \\
\text { Decision }\end{array}$ & \\
\hline Store Services & 0,475 & - & 0,005 \\
\hline $\begin{array}{c}\text { Store } \\
\text { Environment }\end{array}$ & 0,577 & - & 0,001 \\
\hline $\begin{array}{c}\text { Purchase } \\
\text { Intention }\end{array}$ & - & 0,948 & 0,0 \\
\hline
\end{tabular}

Store service significantly proved to have a significant and quite strong influence on purchase intention, the total effect was $47.5 \%$. Although, this research is conducted in Muslim perspectives, the results of this research are similar to those carried out by (10) (11) (12) The cause of store service has a strong influence on the purchase intention because the Muslim people in shopping behavior days are colored by their religion. Where they are hard to believe if the retail sellers and managers are mostly non-Muslims especially from transparency aspects, halal standards, more open communication standards, honesty and low profile (not to be arrogant and arrogant).

Furthermore, the total effect of store environment on purchase intention was $57.7 \%$ and was significant. Its influence is also included in the strong criteria. The factor that determines the influence of this variable is the factor of the atmosphere of a comfortable environment and the lighting is not dazzling the eyes. The meaning is that Muslim consumers like the atmosphere that is calm, not noisy, clean, bright colors, safe, fresh air and refreshing lighting. This is because Muslim consumers in their religion are ordered to clean and maintain the environment properly. The results of this study support the findings of study conducted by (13) that a comfortable environment increases buying interest and consumer purchasing decisions. The difference with this research is in terms the perspective of Muslim consumers.

Empirically, this research has proven that in the view of Muslim consumers, the determinants that influence purchase intention in retail are empathy / service to quickly handle complaints, professional sellers, pleasant store environment and comfortable light in the eyes. While the physical completeness factor of the store and the display of goods have a correlation with the four factors. Purchase intention is also proven to influence consumer buyer decisions.

There is no consensus in store image, it lets alone store image about retail from the perception of Muslim consumers. This study succeeded in explaining the views of Muslims about store image. Store image has proven 
influence on purchase intention consists of store service (empathy, professional seller) and store environment (pleasant environment and lighting). This study is similar to the findings of $(4,14)$. The dimensions of physical facilities (physical facilities and displays) are not proven to have a direct effect on purchase intention and buying interest, but only correlate with store services and store environments. Physical store facilities are actually part of a store, such as: parking lot, front view, logo, shop name, promotion tool, toilet, waiting area and others. This physical facility will not benefit Muslim consumers if it is not usable, dirty and not well-maintained. For Muslim consumers, this is the cause of physical facilities that have no direct influence on buying interest and purchasing decisions.

(12) reminded that the right store image encourages consumers to make purchases. In Muslim consumers, the determining factor of store image for them is store services and store environments. Researcher's findings, environment important factors improve store image (13) encourage people to shop (15) and as a tool to influence consumer behavior (16). An organized environment can make customers come to shop to see and shop (17)

Entrepreneurs and retail managers who run businesses in Muslim-majority countries, invest in developing professional sellers, training their employees' sense of empathy and creating a pleasant atmosphere in their shop area. The accumulation of the availability of clean, safe, pleasant areas and the professional nature of employees (friendly, easy to smile, neat, polite, be honest) and other factors, will arise to the good name of retail stores. Konuk's research (12) proves that building a good store image can increase buying interest and entrepreneurs need to invest in building that positive image. Efforts are needed that are serious about building and developing a store image. One of the ways is to develop salesmen or saleswomen.

The development of salesmen/ sales women is tailored to the needs of the local community $(11,18)$ Studying the culture and behavior of local consumers is very much needed as an employee development material. For consumers who are predominantly Muslim, employee development is tailored to their needs. The main goal of employee development is to improve service quality for buyers. Quality of service is a seller's activity that adds value to merchandise (19) This is where the focus of retail employee development activities, namely to add value to merchandise such as: goods packaging, display, merchandise maintenance, labeling, mixing several items into new products, promotion of goods, use of retail technology, knowledge of merchandise, communicating with consumers, serving complaint, delivery, build personal personality, honest, polite, or other.

Satisfactory service from the seller is felt by the senses of consumers. The results (10) of concluded that skilled and knowledgeable seller interaction increases the number of consumers. Furthermore, the Swoboda study, et al (2007) found that service quality determines that people choose stores. Quality service key factors increase buying interest and purchasing decisions. Buying interest is seen from the willingness of consumers to visit and want to own an item that is sold. From buying interest there will be buying actions / purchasing decisions. The purchase decision at retail is also determined by the payment media (cash, credit, and debit) as well as the speed of payment execution at the checkout. The research results of (20) state that people tend to not like queuing too long to make payments in the air.

For Muslim consumers, research data prove that buying interest and purchasing decisions are not only determined by services but also by an adequate environment. The creation of a comfortable environment is also determined by humans. So, to be able to increase consumer buying interest and increase retail sales, it is highly dependent on retail HR (owners, managers and employees of retail stores) to serve consumers and provide a convenient store environment for prospective consumers.

\section{CONCLUSION}

The store atmosphere is a physical combination of storefronts that have been planned by the owner of the store manager. Store atmosphere is described as a change in the physical design of the store, environmental engineering (air, color, floor, sound, light) with the aim of producing special emotional effects, such as the emergence of attention, willingness to visit shops, buying desires and buying actions. Store Layout. Store layout is the arrangement of goods in the area and available space. Store layout focuses on setting up merchandise, form of goods, arrangement and size of aisle, arrangement of goods shelves Giving direction / location of goods and item shelf labels also includes store layout. Store layout is a part of store atmosphere. A good store layout will attract the attention of visiting customers, making it easier to find and select the desired items and motivate them to shop. Store layouts affect consumer behavior. Putting items in a strategic place will encourage consumers to buy these items. Therefore, shops in strategic locations are visited by many people.

There are various variants that can be developed from Muslim perspectives on the concept of store image, purchase intention and buying decision. This study found that store image variables consist of factors: environment, lighting, empathy, professional sellers, displays and physical facilities of retail stores. While the purchasing decision variable consists of attention to goods, the desire to shop for goods, pay media and the speed of payment at the checkout.

The practical implication is that retail managers and owners whose consumers are predominantly Muslim, need to develop retail service standards including creating store environments in accordance with the needs of Muslim consumers, taking into account the characteristics of each region. The theoretical implications of the store image and purchase intention and buying decision concepts need to be developed for other types of retail.

\section{ACKNOWLEDGMENT}

The researchers would like to say thanks to Sulfikar Sallu ID Scopus 57200989289 doctoral students of Education Technology, Jakarta State University, and Lecturer at the Faculty of Information Technology, Universitas Sembilanbelas November, Kolaka Southeast Sulawesi Indonesia, who assist the researchers during their research completion.

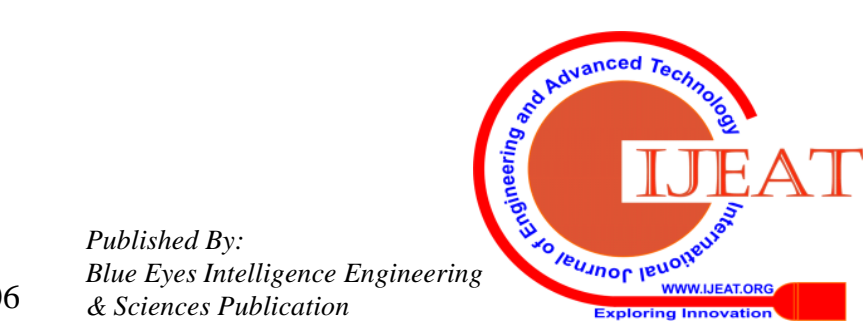




\section{REFERENCES}

[1] Greg Portell MW. The Age of Focus. ATKearney Global Retail Development Index. 2017:52.

[2] Martineau P. The personality of the retail store. Harvard Business Review. 1958;36:79.

[3] Erdil TS. Effects of customer brand perceptions on store image and purchase intention: An application in apparel clothing. Procedia Social and Behavioral Sciences 2015;207:9.

[4] Grewal D, Krishnan, R., Baker, J., Borin, N. The effect of store name, brand name and price discounts on consumers' evaluations and purchase intentions. J. Retail. Journal Of Retailing. 1998;74(3):22.

[5] Khare A. Consumer-small retailer relationships in Indian retail. Facilities. 2014;32(9/10):533-53.

[6] Bèzes C. Definition and psychometric validation of a measurement index common to website and store images. Journal of Business Research. 2014;67(12):2559-78.

[7] Chang CH, Tu C.Y. Exploring Store Image, Customer Satisfaction and Customer Loyalty Relationship: Evidence from Taiwanese Hypermarket Industry. The Journal of American Academy of Business, Cambridge. 2005;7(2):5.

[8] Ghozali I. Model Persamaan Struktural, Konsep \& Aplikasi dengan Program Amos 16.0. 2008.

[9] Didin Kartikasari ZA, Kadarisman Hidayat. PENGARUH PERILAKU KONSUMEN TERHADAP KEPUTUSAN PEMBELIAN. 2013.

[10] Das A, Kumar V, Saha GC. Retail service quality in context of CIS countries. International Journal of Quality \& Reliability Management. 2010;27(6):658-83.

[11] McKenzie B. Retail service quality success factors in Estonia: a qualitative approach. Baltic Journal of Management. 2006;1(3):352-69.

[12] Konuk FA. The role of store image, perceived quality, trust and perceived value in predicting consumers' purchase intentions towards organic private label food. Journal of Retailing and Consumer Services. 2018;43:304-10.

[13] Malaika Brengman KW. Determinants of fashion store personality: a consumer perspective. Journal of Product \& Brand Management. 2009.

[14] Berman B, Evans, Joel R.,. 2007, English, Book, Illustrated edition:\. Retail management : a strategic approach / Barry Berman, Joel R Evans. 10th ed.: Upper Saddle River, NJ : Pearson/Prentice Hall, 2007.; 2007. p. 682.

[15] Kaltcheva VDaW, B.A. When should a retailer create an exciting store environment? Journal of Marketing. 2006;70(1):13.

[16] Lunardo R, Roux D. In-store arousal and consumers' inferences of manipulative intent in the store environment. European Journal of Marketing. 2015;49(5/6):646-67.

[17] Tomazelli J, Broilo PL, Espartel LB, Basso K. The effects of store environment elements on customer-to-customer interactions involving older shoppers. Journal of Services Marketing. 2017;31(4/5):339-50.

[18] Belwal R, Belwal S. Factors affecting store image and the choice of hypermarkets in Oman. International Journal of Retail \& Distribution Management. 2017;45(6):587-607.

[19] . Merrilees B, Miller D. Superstore interactivity: a new self-service paradigm of retail service? International Journal of Retail \& Distribution Manageent. 2001;29(8):379-89.

[20] van Riel ACR, Semeijn J, Ribbink D, Bomert-Peters Y. Waiting for service at the checkout. Journal of Service Management. 2012;23(2):144-69. 